\title{
REAC Cervicobrachial Neuromodulation Treatment of Depression, Anxiety, and Stress During the COVID-I 9 Pandemic [Corrigendum]
}

Pinheiro Barcessat AR, Nolli Bittencourt M, Duarte Ferreira The authors apologize for this error.

L, et al. Psychol Res Behav Manag. 2020;13:929-937.

The authors have advised there is an error in the author list on page 929. The author name "Erick de Souza Neri" should read "Erick Souza Neri”.

\section{Publish your work in this journal}

Psychology Research and Behavior Management is an international, peer-reviewed, open access journal focusing on the science of psychology and its application in behavior management to develop improved outcomes in the clinical, educational, sports and business arenas. Specific topics covered in the journal include: Neuroscience, memory and decision making; Behavior modification and management; Clinical applications; Business and sports performance management; Social and developmental studies; Animal studies. The manuscript management system is completely online and includes a very quick and fair peer-review system, which is all easy to use. Visit http://www. dovepress.com/testimonials.php to read real quotes from published authors. 